\title{
Peran Pemerintah dan Pembangunan Sosial sebagai Pemenuhan Hak Asasi Rakyat
}

\author{
Suharto
}

Since at the end of decade of the twentieth century, the trends of the strength of the market economy regime, the intervention of government in economic face the pressure. In the context of development, the pressure in minimizing government intervention because of the proof regarding the failure in conducting its role. The development of economy increases the growth of economy without able to overcome the problem of the chasm and the poverty. The problems as mentioned above raise because development of economy does not equalize social development. To liberate society from poverty constitutes the actualization of filling human right. Accordingly, the social role of government in abolishing poverty denotes the human obligation rights that should be carried out by government.

Sejak dekade terakhir abad 20, seiring dengan kecenderungan menguatnya rezim ekonomi pasar, campur tangan pemerintah dalam perekonomian mendapat tekanan. Dalam konteks pembangunan, tekanan untuk mengurangi campur tangan pemerintah disebabkan adanya bukti kegagalan pemerintah di dalam menjalankan perannya. Inefisiensi Badan Usaha Milik Negara (BUMN) dan korupsi dalam segala bentuknya merupakan manifestasi kegagalan tersebut, yang ujungnya gagal mewujudkan kesejahteraan masyarakat.

Dalam perjalanan sejarah teori ekonomi, mashab-mashab besar seperti Klasik, Austria, Neo-Klasik, mekanisme pasar menjadi andalan analisis pertumbuhan ekonomi dan efisiensi. Ide dasarnya adalah berjalannya mekanisme pasar dilandasi oleh pengambilan keputusan secara individu. Dengan demikian akan menciptakan rangsangan (insentif) untuk belajar yang mendorong terjadinya penemuan-penemuan baru yang kemudian diaplikasikan dalam pasar (inovasi). Melalui bekerjanya pasar secara sempurna maka perekonomian akan mencapai kondisi pareto optimum, di mana efisiensi dalam. produksi dan distribusi komoditi terpenuhi bersamasama dan serentak dengan kondisi optimum konsumen. Dalam pemikiran demikian peran pemerintah dapat diterima dalam tingkat yang minimal (hankam, hukum, pendidikan, kesehatan dan memenuhi barang-barang publik lainnya). Di samping itu peran pemerintah diperkenankan dalam rangka mengatasi kegagalan pasar (monopoli/ oligopoli, eksternalitas, ketidaksempurnaan informasi dan sebagainya).

Pembangunan sosial adalah peran pemerintah yang fundamental di dalam proses pembangunan secara keseluruhan. Fakta menunjukkan bahwa pertumbuhan ekonomi yang terjadi di negara-negara berkembang diikuti oleh berbagai permasalahan sosial yang kronis dalam bentuk kemiskinan, pengangguran dan kesenjangan. Pembangunan sosial menurut Moeljarto dan Prabowo (1997) pada dasarnya merupakan suatu program kesejahteraan atau bantuan bagi orang miskin melalui kebutuhan dasarnya, yang mencakup bukan 
hanya kesempatan memperoleh penghasilan melainkan juga akses terhadap pelayanan publik seperti pendidikan, kesehatan, perumahan, transportasi, dan air bersih.

Dalam kenyataannya, pembangunan sosial selama ini jauh tertinggal dari pembangunan ekonomi. Kecenderungannya pembangunan ekonomi berjalan sendiri, terpisah dari pembangunan sosial. Sehingga banyak ditemukan fakta bahwa indikatorindikator ekonomi tidak berkorelasi secara kuat dengan indikator-indikator sosial (Ram, 1992, Hill dan William, 1989). Terlebih apabila pembangunan ekonomi dilihat sebagai pertumbuhan ekonomi semata.

\section{Lepas dari Kemiskinan adalah Hak Asasi Manusia}

Perwujudan hak asasi manusia pada - dasarnya adalah terbebasnya manusia dari ketergantungan kepada pihak lain. Masyarakat yang terhimpit dalam kemiskinan tidak saja mendapatkan bagian yang tidak adil dalam menikmati hasil-hasil pembangunan dibandingkan dengan kelompok masyarakat lain yang lebih mampu, tetapi juga terkait dengan keterbatasan dalam mengekspresikan hakhak dasarnya. Orang miskin tidak memiliki kebebasan memilih dalam segala hal, tidak memiliki rasa aman, dan seterusnya. Dalam konteks riil orang miskin umumnya tidak memiliki akses yang memadai terhadap pelayanan maupun fasilitas publik. Oleh karena itu cara efektif untuk menjamin terpenuhinya hak asasi manusia adalah dengan terus berupaya menghilangkan kemiskinan.

Tugas pemberantasan kemiskinan merupakan kewajiban asasi yang harus dilakukan pemerintah. Apabila pemerintah tidak mampu menghilangkan kemiskinan, apalagi kemiskinan semakin besar maka pemerintah dapat dikatakan gagal. Karena pemerintah tidak mampu menjamin rakyatnya mendapatkan hak asasinya.

\section{Pembangunan Sosial: Mengapa?}

World Summit for Social Development yang berlangsung di Kopenhagen pada Maret 1995 disebut sebagai titik yang paling tegas, awal perhatian internasional terhadap pembangunan sosial (Moeljarto dan Prabowo, 1997; UNRISD, 2000). Pertemuan ini berlangsung bersamaan dengan keyakinan para pendukung pasar bebas bahwa kebijakan-kebijakan neo-liberal akan memberikan hasil yang baik untuk semua. Namun pada kenyataannya, kemiskinan dan pengangguran meningkat pesat di negaranegara dunia ketiga yang mengalami permasalahan utang luar negeri. Hal ini kemudian memunculkan pendapat bahwa utang luar negeri akan menghambat pembangunan sosial.

Data yang ada menunjukkan bahwa sekalipun pertumbuhan ekonomi dunia terus terjadi, namun indikator-indikator pembangunan sosial tidak berkembang secara memadai. Dengan kata lain, pembangunan sosial dalam kenyataannya tidak berlangsung sebagaimana dikehendaki oleh masyarakat.

Dalam kurun waktu 1991-1999, ekonomi dunia tumbuh setidaknya $1,8 \%$ per tahun (1991) dan tertinggi 4,3\% pada 1996. Negara berkembang mengalami pertumbuhan lebih tinggi daripada negara maju (khususnya.di wilayah Asia), sementara untuk negaranegara dalam transisi (Erapa Timur dan Tengah) lebih banyak mengalami kemerosotan ekonomi. Kendät demikian, secara umum menunjukkan bahwa perekonomian mengalami pertumbuhan (tabel 1).

Namun pada tabel 2, menunjukkan bahwa penurunan jumlah penduduk miskin (menerima pendapatan di bawah 1 dollar per hari) tidak berlangsung secara cepat. Pada 1987 jumlah penduduk miskin dunia tidak 
sampai 1,2 milyar orang, pada 1997 justru lebih dari 1,2 milyar. Padahal ukuran demikian tidak memadai untuk menggambarkan permasalahan yang sebenarnya (UNRISD, 2000, 11). Namun demikian data tersebut memberikan gambaran jumlah penduduk miskin amat besar ( $1 / 5$ dari total penduduk dunia).

Meningkatnya kemiskinan ini menurut laporan UNRISD bukan karena dunia secara keseluruhan semakin miskin, melainkan penyebaran manfaat pertumbuhan ekonomi cenderung tertinggal di belakang pembangunan ekonomi. Fakta demikian harus dipahami bahwa pembangunan sosial harus disadari penting untuk diprioritaskan. Moeljarto dan Prabowo (1997) menyebutkan bahwa pembangunan sosial tidak semata-mata by product dari pembangunan ekonomi tetapi memerlukan penanganan secara khusus. Memang, pembangunan ekonomi termasuk pertumbuhan ekonomi bukannya tidak penting, tetapi tidak cukup. Apabila

Tabel 1. Prosentase Pertumbuhan Ekonomi tahun 1991-1999

\begin{tabular}{|l|r|r|r|r|r|r|r|r|r|}
\hline \multicolumn{1}{|c|}{ Wilayah } & 1991 & 1992 & 1993 & 1994 & 1995 & 1996 & 1997 & 1998 & 1999 \\
\hline Dunia & 1.8 & 2.7 & 2.7 & 4 & 3.7 & 4.3 & 4.2 & 2.5 & 2.3 \\
\hline Negara.Maju & 1.2 & 1.9 & 1.2 & 3.2 & 2.6 & 3.2 & 3.2 & 2.2 & 2 \\
\hline Negara Berkembang & 4.9 & 6.7 & 6.5 & 6.8 & 6.1 & 6.5 & 5.7 & 3.3 & 3.1 \\
\hline Afrika & 1.8 & 0.2 & 0.7 & 2.2 & 3.1 & 5.8 & 3.1 & 3.4 & 3.2 \\
\hline Asia & 6.6 & 9.5 & 9.3 & 9.6 & 9.1 & 8.2 & 6.6 & 3.8 & 4.7 \\
\hline Timur Tengah dan Eropa & 2.7 & 7 & 4 & 0.6 & 3.7 & 4.7 & 4.4 & 2.9 & 2 \\
\hline Western hemisphere & 3.9 & 3.3 & 3.9 & 5.2 & 1.3 & 3.6 & 5.2 & 2.3 & -0.5 \\
\hline Negara Transisi & -7.4 & -11.7 & -6.4 & -7.5 & -1.1 & -0.3 & 2.2 & -0.2 & -0.9 \\
\hline
\end{tabular}

Sumber: UNRISD, 2000:8

sangat timpang. Estimasi UNDP, badan PBB yang mengurusi pembangunan manusia, bahwa jarak antara negara kaya dengan negara miskin makin jauh, apabila pada 1973 masih 44 banding 1 , pada 1992 justru mencapai 72 banding 1. Dengan kata lain proses ketimpangan terus berlangsung.

Ditinjau dari ketimpangan tersebut, bila diukur dengan menggunakan koefisien Gini, negara-negara kawasan Amerika Latin menunjukkan angka terburuk dengan Brazil sebagai yang terburuk. Setelah itu diikuti oleh negara-negara Sub-Sahara Afrika, dan Asia masih lebih buruk dibandingkan dengan negara-negara maju (OECD). Hal ini mengindikasikan pula bahwa wilayah yang ekonominya tumbuh cepat belum tentu tingkat pemerataan pendapatannya juga baik.

Gambaran di atas merupakan bukti bahwa selama ini pembangunan sosial mengacu pada tujuan tradisional dari pertumbuhan ekonomi, seperti yang disebutkan oleh Griffin (1997), adalah pertumbuhan ekonomi yang menekankan pada peningkatan output baik barang dan jasa dengan harapan bahwa hal ini akan mendorong meningkatnya kesejahteraan masyarakat dan menurunkan tingkat kemiskinan.

Namun kenyataan berbicara lain. Krisis ekonomi yang melanda Asia membuktikan bahwa mitos tersebut tidaklah benar. Meningkatnya pengangguran adalah dampak langsung dari krisis ekonomi. Catatan United Nations Research Institute for Social Development/UNRISD (2000) mencatat bahwa tingkat pengangguran di negara-negara Asia meningkat dua kali lipat pada masa depresi 1997-1998. Sementara di Amerika Latin, tingkat pengangguran pada tahun 1998 adalah yang tertinggi selama 15 tahun 
Tabel 2. Kecenderungan Kemiskinan: Masyarakat yang Berpenghasilan di Bawah \$1 per Hari (Juta)

\begin{tabular}{|l|r|r|r|r|r|}
\hline \multicolumn{1}{|c|}{ Wilayah } & \multicolumn{1}{c|}{$\mathbf{1 9 8 7}$} & \multicolumn{1}{c|}{1990} & \multicolumn{1}{c|}{$\mathbf{1 9 9 3}$} & \multicolumn{1}{c|}{$\mathbf{1 9 9 6}$} & \multicolumn{1}{c|}{1998} \\
\hline Asia Timur dan Pasifik & 415.1 & 452.4 & 431.9 & 265.0 & 278.3 \\
\hline Di luar China & 109.2 & 76.0 & 66.0 & 45.2 & 55.6 \\
\hline Eropa Timur dan Asia Tengah & 1.1 & 7.1 & 18.3 & 23.8 & 24.0 \\
\hline Amerika Latin dan Karibia & 63.7 & 73.8 & 70.8 & 76.0 & 78.2 \\
\hline Timur Tengah dan Afrika Utara & 25.0 & 22.0 & 21.5 & 21.3 & 20.9 \\
\hline Afrika Selatan & 474.4 & 495.1 & 505.1 & 504.7 & 522.0 \\
\hline Afrika Sub Sahara & 217.2 & 242.3 & 273.3 & 289.0 & 290.9 \\
\hline Total & $\mathbf{1 , 1 9 6 . 5}$ & $\mathbf{1 , 2 9 2 . 7}$ & $\mathbf{1 , 3 2 0 . 9}$ & $\mathbf{1 , 1 7 9 . 9}$ & $\mathbf{1 , 2 1 4 . 2}$ \\
\hline Di luar China & 890.6 & 916.3 & 955.0 & 960.1 & 991.5 \\
\hline
\end{tabular}

Sumber: UNRISD, 2000:11

terakhir. Akhirnya, demi untuk mendapatkan pekerjaan mereka rela untuk bekerja pada pekerjaan-pekerjaan tidak tetap atau pun bersifat paruh waktu. Misalnya di kawasan Sub-Sahara Afrika sebesar $2 / 3$ pekerjaan adalah informal. Hal ini belum dilihat dari rendahnya tingkat upah. Diungkapkan bahwa tingkat upah riil di Amerika Latin dan Afrika saat ini masih belum kembali pada masa normal dua puluh tahun yang lalu.

Di Indonesia, krisis ekonomi 1997 telah membuat pengangguran mencapai angka 35 juta orang sebagian besar adalah tenaga kerja . berusia muda dan berpendidikan memadai. Jumlah penduduk miskin juga melonjak, sehingga tidak aneh jika sektor informal menjadi rebutan, dan kriminalitas merajalela.

Semua gambaran di atas sekali lagi menunjukkan bahwa mengurangi kemiskinan melalui proses pertumbuhan ekonomi tidak dapat diteruskan lagi. Dengan kata lain diperlukan penanganan khusus terhadap pembangunan sosial. Hal ini sudah digarisbawahi dalam Deklarasi dan Program Aksi yang dihasilkan oleh pertemuan Kopenhagen. 1995 yang secara garis besar menekankan pada pentingnya equity, partisipasi, pemberdayaan, dan solidaritas. Dalam deklarasi tersebut juga terdapat komitmen dari 117 kepala negara atau. pemerintahan untuk menciptakan suatu lingkungan ekonomi, politik, sosial, budaya dan hukum yang memungkinkan masyarakat mencapai pembangunan sosial (UNRISD, 2000). Terhadap kondisi yang ada sekarang ini, UNRISD menyatakan bahwa lima tahun setelah pertemuan Kopenhagen, nyaris tidak ada indikasi bahwa tujuan maupun nilai-nilai fundamental dalam orientasi pembangunan dunia mengarah pada tanggung jawab sosial yang lebih besar.

Tabel 3. Koefisien Gini 1997, Beberapa Negara

\begin{tabular}{|c|c|c|}
\hline Wiayah & Negara & Koefisien GInI \\
\hline \multirow[t]{5}{*}{ OECD } & Amerika Serikat & $0.34-0.35$ \\
\hline & Jepang & $0.34-0.35$ \\
\hline & United Kingdom & 0.32 \\
\hline & Swedia & 0.32 \\
\hline & Australia & 0.32 \\
\hline \multirow[t]{5}{*}{ Asia } & China & $0.35-0.36$ \\
\hline & Bangladesh & $0.35-0.36$ \\
\hline & Indonesia & $0.31-0.32$ \\
\hline & India & $0.30-0.31$ \\
\hline & Pakistan & $0.30-0.31$ \\
\hline \multirow[t]{5}{*}{ Amerika Latin } & Brazil & 0.61 \\
\hline & Honduras & 0.6 \\
\hline & Chile & 0.56 \\
\hline & Columbia & 0.490 .5 \\
\hline & Mexico & $0.47-0.48$ \\
\hline \multirow[t]{6}{*}{ Añika Subsahara } & Ańrika Utara & 0.58 \\
\hline & Kenya & 0.57 \\
\hline & Zambia & $046-0.47$ \\
\hline & Nigenáa & $0.45-0.46$ \\
\hline & Ethiopia & $0.44-0.45$ \\
\hline & Ghana. & $0.33-0.34$ \\
\hline
\end{tabular}

Sumber. UNRISD, 2000:12 . 


\section{Peran Pemerintah}

Menurut Moeljarto dan Prabowo (1997), terdapat tiga kategori makna pembangunan sosial, yaitu:

1. Pembangunan sosial sebagai pengadaan pelayanan masyarakat. Di sini, pembangunan sosial diartikan sebagai upaya memenuhi kebutuhan dasar manusia seperti pendidikan, kesehatan, pangan, sandang, dan perumahan. Dalam hal ini pemerintah cenderung menempatkan manusia sebagai aktor yang harus 'pasif' menerima pelayanan apa pun yang diberikan oleh birokrasi pemerintahan sesuai dengan kebijaksanaan mereka, dengan cara, waktu, dan tempat yang telah ditentukan oleh birokrasi. Sehingga konsep ini mendekati metode konvensional top down yang bercirikan charity strategy.

2. Pembangunan masyarakat sebagai upaya terencana untuk mencapai tujuan sosial yang kompleks dan bervariasi. Dalam hal ini tidak hanya menekankan aspek pelayanan sosial saja. Tujuan utama pembangunan sosial adalah melibatkan setiap pribadi dalam proses pembebasan dirinya sendiri dari setiap bentuk dan dominasi atau tekanan, sehingga setiap individu dapat tumbuh secara lengkap dalam hubungannya dengan orang lain.

3. Pembangunan sosial sebagai upaya terencana untuk meningkatkan kemampuan manusia untuk bertindak. Di sini meliputi suatu usaha terencana untuk meningkatkan kemampuan dan potensi manusia, dan untuk mengerahkan minat mereka ikut serta dalam proses pembentukan keputusan mengenai berbagai hal yang memiliki dampak pada mereka maupun bagi penerapan keputusan tersebut.

Dari makna-makna pembangunan sosial tersebut dapat disebutkan bahwa peran pemerintah penting. Seperti diungkapkan Weimer dan Vining (1992), peran pemerintah dengan kebijakan publiknya adalah termasuk merealokasi oportunitas dan barang untuk mencapai nilai-nilai distribusional yang tidak selalu dapat dipenuhi mekanisme pasar.

Oleh sebab itu kebijakan pemerintah akan turut menentukan tingkat pembangunan sosial yang dicapai oleh suatu negara. Hal ini tidak berarti mengingkari bahwa pembangunan sosial juga membutuhkan pertumbuhan ekonomi dan kebijakan fundamental ekonomi makro yang benar. Namun kedua hal tersebut tidaklah cukup bagi pembangunan sosial karena pembangunan sosial juga membutuhkan adanya kebijakan sosial dan distribusi yang baik dari hasil-hasil pertumbuhan. Begitu pula halnya dengan kelembagaan yang efektif, termasuk dengan memperkuat peran negara yang makin efisien, transparan dan accountable.

Yang menarik dan sekaligus menjadi persoalan dalam pembangunan sosial, di negara-negara berkembang ada kecenderungan terjadinya pengurangan pengeluaran publik. Disebutkan oleh UNRISD (2000) bahwa antara 1990 dan 1997, pengeluaran publik sebagai persentase dari Produk Domestik Bruto turun dari 26\% menjadi 22\% di Sub-Sahara Afrika. Sementara di negara-negara OECD justru mengalami peningkatan dari $45 \%$ menjadi $47 \%$.

Mengapa di negara maju meningkat sementara di negara berkembang justru sebaliknya? Hal ini disebabkan karena resistensi warga negara di negara maju yang demokratis sehingga jika terjadi penurunan sangatlah kecil. Sementara di negara berkembang, resistensi itu boleh dikatakan tidak ada. Kondisi di negara berkembang lebih akut lagi karena adanya anggaran pemerintah mendapat tekanan dari beban utang luar negeri. Dengan kata lain, kemampuan keuangan negara menjadi kendala dalam pembangunan sosial, terutama akibat beban utang yang sangat berat tadi. 


\section{Peran Pemerintah dan Pembangunan Sosial sebagai Pemenuhan Hak Asasi Manusia}

Memang selama ini-alokasi anggaran untuk pembangunan sosial terus meningkat. Apabila pada Repelita I baru $10,93 \%$ dari total anggaran pengeluaran pembangunan, pada Repelita V. sudah mencapai $20,72 \%$ (tabel 4). Namun alokasi ini relatif kecil bila dibandingkan dengan pengeluaran untuk sektor-sektor ekonomi. Untuk sektor perhubungan dan pariwisata misalnya, pada Repelita $\mathrm{V}$ mendapatkan $19.863,8$ miliar atau mendekati total pengeluaran seluruh pembangunan sosial.

Prospek pembangunan sosial kemudian cenderung memburuk ketika dihadapkan dengan persoalan beban utang yang dihadapi Indonesia. Morgan Stanley Dean Witter (MSDW), sebuah bank investasi yang berbasis di London, dalam laporannya menempatkan Indonesia sebagai kandidat utama negara yang terpeleset ke dalam sektor sosial, : seperti pendidikan, kesehatan, serta program-program jaminan sosial. Hal ini adalah salah satu penjelas penting mengapa subsidi banyak dipangkas. Memang banyak penyimpangan subsidi sehingga mesti diluruskan tetapi jelas ada subsidi yang memang diperlukan di tengah beban sosial yang luar biasa. Reformasi anggaran dengan penghèmatan pengeluaran untuk pembangunan sosial adalah pilihan yang harus dijalani berkaitan dengan utang luar negeri. Hal ini menegaskan bahwa utang luar negeri menjadi penghambat pembangunan sosial bersama-sama dengan penyimpangan anggaran negara yang mestinya digunakan untuk pembangunan sosial.

Tabel 4. Pengeluaran Pembangunan Sosial, Pelita I-V (miliar rupiah)

\begin{tabular}{|c|c|c|c|c|c|c|}
\hline No & Sektor & $\mathbf{I}$ & II & III & $\mathbf{n}$ & $\mathbf{v}$ \\
\hline 9 & $\begin{array}{|lrr|}\text { Pendidikan, } & \text { Generasi } & \text { Muda, } \\
\text { Kebudayaan } & \text { nasional } & \text { dan } \\
\text { Kepercayaan terhadap Tuhan } & \text { YME }\end{array}$ & 83,8 & 758,1 & $3.397,1$ & $6.615,1$ & $12: 686,5$ \\
\hline 10 & $\begin{array}{l}\text { Peranan Wanita, Kependudukan } \\
\text { dan KB }\end{array}$ & 27,3 & 262,0 & $1.184,0$ & $1.608,2$ & $4.127,8$ \\
\hline & Perumahan rakyat dan Pemukiman & 23,7 & 195,3 & 845.9 & $1.808,3$ & $3.998,4$ \\
\hline \multirow{2}{*}{\multicolumn{2}{|c|}{ Total Pengeluaran Pembangunan sosial }} & 134,8 & $1.215,0$ & 50426,0 & $9.031,6$ & $20.912,4$ \\
\hline & & $-10.93 \%$ & $-13.32 \%$ & $-15.90 \%$ & $-17.75 \%$ & $-20.7 \cdot 2 \%$ \\
\hline \multicolumn{2}{|r|}{ Total Pengeluaran Pembangunan } & $1.232,8$ & $9: 126,4$ & $34.129,2$ & $50.885,1$ & $100: 912,2$ \\
\hline
\end{tabular}

Sumber: diringkas dari Moeljarto dan Prabowo (1997): tabel 10

perangkap utang bersifat permanen (permanent debt trap).

Hal itu akan menyebabkan output nasional terserap untuk membayar utang. Tahun 2000 menunjukkan $8 \%$ dari PDB terserap untuk membayar kewajiban utang luar negeri. APBN 2001 sebanyak $40 \%$ di antaranya terserap untuk membayar bunga obligasi rekapitalisasi perbankan yang tidak ada tanda-tanda yang memuaskan.

Dengan kondisi semacam itu, negara tidak lagi banyak berbuat untuk sektor-

\section{Solusi Pembiayaan}

Dálam kondisi seperti di atas muncul pertanyaan mengenai siapa yang bertanggung jawab dalam pembiayaan pembangunan sosial? Dalam laporan. UNRISD (2000) mencatat ada sejumlah hal yang dapat dilakukan oleh pemerintah untuk mengatasi persoalan keterbatasan anggaran tersebut. Jika pemerintah ingin mencapai pembangunan yang lebih adil maka pemerintah harus menyelesaikan 
krisis utang dan melakukan reorientasi terhadap bantuan pembangunan. Pemerintah juga perlu mengadopsi pendekatan-pendekatan baru terhadap perpajakan, dana pensiun, dan menemukan cara-cara lain yang dapat mendorong sumberdaya lokal.

Menyelesaikan Krisis Utang Luar Negeri

Seperti sudah diungkapkan di depan, bebạn utang yang sangat berat menjadi penghambat pembangunan sosial. Penyelesaian tuntas atas utang tidak lain dengan penghapusan utang. Namun dalam masalah ini setidaknya ada dua kendala. Pertama, pihak pemberi utang enggan memberikan penghapusan utang. UNRISD mencatat bahwa upaya penghapusan utang untuk Heavily Indebted Poor Country (HIPC) yang dilansir Bank Dunia dan IMF 1996, sampai sekarang tidak banyak kemajuan. Total utang HIPC sebetulnya hanya sekitar $10 \%$ dari total utang dunia ketiga. Sementara itu, pemerintah negara sedang berkembang, seperti Indonesia, tidak menampakkan keseriusan untuk menunjukkan keseriusan penghapusan utang.

\section{Reorientasi terhadap Bantuan} Pembangunan

Kalaupun sudah mendapatkan penghapusan utang, negara-negara miskin tetap membutuhkan bantuan lainnya. Negaranegara tersebut tetap membutuhkan aliran dana segar dari luar negeri untuk memperkuat perekonomiannya yang sebagian besar justru dapat dipenuhi oleh bantuan pembangunan. Dalam hal ini bantuan pembangunan tidak hanya untuk membiayai proyek-proyek penting tetapi juga menarik modal asing masuk. Namun pengalaman yang ada menunjukkan bahwa pihak negara donor seringkali tidak peduli terhadap penggunaan dari bantuan-bantuan yang diberikannya. Maka terjadilah penyimpangan-penyimapngan yang baru belakangan ini dipersoalkan oleh pihak donor. Dengan mengingat kondisi demikian dibutuhkan reorientasi bantuan pembangunan, caranya dengan mengalokasikan dana lebih besar bagi pembangunan sosial sehingga negara yang menerima bantuan memiliki kesempatan yang lebih besar dalam melakukan pembangunan sosial.

\section{Reformasi Perpajakan}

Reformasi perpajakan juga dibutuhkan agar penerimaan pemerintah lebih besar, sehingga tersedia dana untuk pembangunan sosial. Selama ini negara kaya memiliki basis pajak yang lebih luas dibandingkan negara miskin, sementara negara miskin memiliki ketergantungan pada pajak ekspor dan impor. Kedua macam pajak tersebut semakin kecil seiring berjalannya liberalisasi ekonomi internasional. Persaingan global menyebabkan kekhawatiran jika negara berkembang menaikkan pajak karena dapat menyebabkan pelarian modal-asing maupun domestik, akibatnya terjadi penurunan tax rate di seluruh dunia. Selain itu, diperlemah oleh dominannya sektor informal dan aktivitas black economy. Sementara itu, liberalisasi juga membuka peluang penyelundupan pajak melalui lalulintas modal internasional.

\section{Reformasi Dana Pensiun}

Program pensiun merupakan elemen penting jaminan sosial. Dana untuk program tersebut akan sangat besar seiring dengan makin banyaknya penduduk lanjut usia. Namun usaha ini sangat rentan terhadap krisis, meningkatkan pengangguran di sektor formal, dan tumbuhnya sektor informal. Tantangan reformasi dana pensiun merefleksikan perdebatan mengenai solidaritas dan resiko. Dalam hal ini juga berkembang berbagai lembaga pensiun swasta, bukan hanya pemerintah. 
Mobilisasi Dana pada Tingkat Akar · Rumput

Di tengah beratnya beban pembayaran utang, turunnya bantuan pembangunan dan merosotnya penerimaan pajak, pemerintah harus melakukan upaya-upaya khusus untuk menggunakan sumbersumber yang langka secara efisien. Dalam hal ini kredit mikro merupakan salah satu bentuk yang paling populer pada tingkat lokal. Pinjaman skala kecil ini memang dapat secara langsung mengatasi masalah yang dihadapi tetapi tidak selalu dapat mengangkat penduduk miskin dari kemiskinannya. Justru kiriman uang dari penduduk yang bekerja di luar negeri sangat membantu menikkan taraf hidup penduduk berpendapatan rendah di negara-negara berkembang.

\section{Penutup}

Paparan di atas mau tidak mau membutuhkan pula reformasi sektor publik, yaitu agar sektor publik makin efektif dan efisien. Pertimbangan utamanya adalah bahwa orang ingin menuju masyarakat yang lebih makmur, merata, dan harmonis. Pada sisi ini, juga menjadi perlu untuk mendesak sektor swasta untuk meningkatkan tanggungjawabnya . terhadap pembangunan sosial. Di masa depan pembangunan sosial harus mendapatkan porsi yang lebih besar dan tidak bisa lagi diintegrasikan begitu saja dengan pembangunan ekonomi. Lebih lanjut keberhasilan pemerintah harus dilihat juga dari kinerja pembangunan sosial yang dilakukan, karena hal ini merupakan perwujudan hak asasi manusia.

\section{Daftar Pustaka}

Griffin, Keith., 1997, "Culture, ,Development and Economic Growth", GenevaParis: UNRISD-UNESCO

Hill, Hal dan Catharina Williams., 1989, "The Economic and Social Dimensions of Regional Development in Indonesia", Ekonomi dan Keuangan Indonesia Vol. 37 No.2

Moeljarto, V dan Sonia Prabowo., 1997., “ Bidang Pendidikan dan Kesehatan dalam Pembangunan Sosial", Analisis CSIS XXVI No. 1 Januari-Februari

Pangestu, M dan Ira Setiati (penyunting)., 1989, Mencari Paradigma Baru Pembangunan Indonesia, Jakarta: CSIS Ram, Rati., 1992, "Income, Distribution, and Welfare: An Intercountry Comparation", Economic Development and Cultural Change, Vol 41 No.1.

UNRISD., 2000, Visible Hands: Taking Responsibility for Social Development, Geneva: UNRISD

Weimer, David L. dan Aidan R. Vining., 1992, Policy Analysis Concepts and Practice, New Jersey: Prentice-Hall. 